\title{
BALANCED SCORECARD FOR SELECTED CONFECTIONERY COMPANIES LISTED ON THE WARSAW STOCK EXCHANGE IN POLAND
}

\author{
Elżbieta Jaworska, Bożena Nadolna \\ West Pomeranian University of Technology Szczecin, Poland \\ elzbieta.jaworska@zut.edu.pl
}

\begin{abstract}
Business managers report the need for modern methods to improve the implementation of organizational strategies. Translating the strategy into activities and monitoring its implementation poses a serious challenge for the management of modern enterprises. The article aims to present proposals for multidimensional performance measurement with the help of Balanced Scorecard (BSC) for selected Polish listed companies in the confectionery industry. The authors' original solution within the framework of the BSC construction is extending the range of perspectives for assessing performance compared to the card proposed by Kaplan and Norton by the perspective of suppliers and CSR, and the appropriate selection of measures for this assessment.

The article is based on literature studies and analysis of information included in business strategies, financial statements and reports on the operations of selected confectionery companies. Research on the use of multidimensional performance measurement using BSC, taking into account the additional perspectives of suppliers and CSR, help to better understand the relationship between economic, social, and environmental aspects of a company's operations. Key words: Balanced Scorecard, performance measurement, strategy, CSR, confectionery industry companies.
\end{abstract}

\section{Introduction}

The condition for effective management of each enterprise is obtaining multidimensional information about the effects of its operations. This particularly applies to enterprises that are dynamically developing and operating in a highly competitive environment. This group of enterprises includes companies dealing in confectionery. The shortage of multidimensional information about the company's performance concerns mainly larger companies, for example, those raising capital on the stock exchange. These performances should be measured. However, the measurement should not be narrowed down to the results of running a business in financial terms, but to also take into account the non-financial indicators. This is connected with the necessity to select appropriate tools in this area. The concept of measuring the results of the company's activities presented widely in the literature are multidimensional cards of achievements, among them the Balanced Scorecard - BSC, developed by Kaplan and Norton (1992). It is discussed in international and national literature on the strategic management of agribusiness companies, and finds wider and wider applications in practice. For example, it was implemented in Zeneca Ag Products, USA (Kaplan \& Norton, 2001), in arable farming in Germany (Paustian, Wellner, \& Theuvsen, 2015), in a dairy farm with small-scale production in Brazil (Cardoso et al., 2017), and in an agricultural company of plant, animal and processing production (bakery) in Romania (Brezuleanu et al., 2015). The concept of using BSC in milk processing in Poland was proposed by Pietrzak (2008), in agrifood companies by Jaworska, Nadolna (2010); while Jaworski \& Kondraszuk (2013) presented the premises for the use of this card on a farm. Soliwoda (2016) reviewed the previous BSC implementations in terms of challenges (difficulties) and opportunities resulting from the practical application of strategic financial management of agricultural enterprises.

Numerous authors emphasize the necessity of close cooperation of agribusiness enterprises within the supply chain, which requires the use of performance measures other than financial ones. The use of the BSC method in managing the supply chain in this area of activity was discussed by Brewer (2002), Hernandez, Rickert \& Schiefer (2003), Bigliardi \& Bottani (2010). The aforementioned authors claim that although the BSC concept was not designed for supply chains, it provides a good guidance for the selection of key performance indicators. Noteworthy are also studies on the possibility of using BSC for management in farms operating within producer groups Noell \& Lund (2003).

The purpose of this article is to propose the construction of a balance BSC for a multidimensional assessment of performance results for selected companies in the confectionery industry, listed on the Warsaw Stock Exchange.

For the purposes of the article, the following research tasks were formulated: 1) study of the theoretical aspects of BSC;2) identification of strategies and directions of their implementation in the surveyed enterprises of the confectionery sector; 3) proposal of multidimensional performance measurement using BSC, taking into account additional supplier perspectives and CSR, which may help managers of these enterprises in making decisions that take into account all aspects of the company's operations. A qualitative study was carried out on source documents of selected companies, which was preceded by a review of available publications on the subject. 


\section{Materials and Methods}

The source material for research is information mentioned in business strategies, financial statements and reports on the operations of selected three Polish listed companies operating in the confectionery sector for the years 2016-2017. The sample selection was purposive. The confectionery sector has development potential and a very significant contribution to the Polish economy. The demand for sweets continues to grow (KPMG, 2014). While selecting the companies, the volume of production and share in the market were taken into consideration. The selected companies are listed on the Warsaw Stock Exchange (WSE). They are: Otmuchów S.A., Wawel S.A., and Colian S.A.

Otmuchów S.A. has been operating on the Polish confectionary production market for over 50 years. It has been operating as Zakłady Przemysłu Cukierniczego OTMUCHÓW Spółka Akcyjna since 1997. Currently the company hires about 800 people and conducts their production activity in three plants. In Otmuchów, plants producing gumdrops and chocolate products are located, while in Nysa there is a plant producing breakfast cereals. The value of the company's assets at the end of the third quarter of 2018 amounted to PLN 202,390,000, while the EBITDA ratio was PLN 3,208,000. The next company is Wawel S.A., which originated as a chocolate factory. It was founded in Kraków in 1898. In 1922, it became a joint-stock company, and since March 1998 its stocks have been listed on the WSE. Currently the company hires about 1000 people. Its core business is the production of chocolate products, wafers and sweets. The value of the company's assets at the end of the third quarter of 2018 amounted to PLN 741.703,000, and EBITDA to PLN 22.974,000. The last company is Colian S.A., which is currently a family business. It was created from the merger of many plants, such as Jutrzenka, Goplana, Kaliszanka, Solidarność, as well as Ziołopex, and Hellena. In 2008, the activities of the capital group based on the 'Jutrzenka' S.A. stock company were consolidated, the shares of which were listed on the parallel market on May 16, 1995, and on the primary market on April 23, 1997. The company currently hires about 1700 people. Its activity includes production of sweets, confectionery, and beverages. The company's assets at the end of the third quarter of 2018 amount to PLN 1,252,319,000, and EBITDA to PLN 2,236,000.

The research is exploratory. The main method used in the article is the method of source analysis and the method of deduction and induction. Taking into consideration the specificity of the sector, the BSC developed by Kaplan and Norton was modified by the authors and used for the purposes of the study.

\section{Results and Discussion}

The BSC is a tool supporting the implementation of the adopted business strategy (Porter \& Kramer, 2006). It constitutes a comprehensive concept related to the measurement and evaluation of its performance (Nita, 2014). It makes it possible to transpose the company's vision and strategy into specific goals and operational measures, which are assigned to at least four perspectives: financial, client's, internal processes, and learning and growth (Kaplan \& Norton, 1992, 1996). For the purposes of business management in the confectionery industry, it is necessary to supplement and extend the classic configuration of Kaplan and Norton's balanced performance card with suppliers' perspective and the CSR perspective.

Identification of strategies and directions of their implementation in selected enterprises of the confectionery industry

The use of BSC to assess the performance of confectionery enterprises requires analysis of the strategy of the units under investigation and the directions of its implementation. The analyzed period covered the years 2017-2018. The classification of strategies in particular units and the directions of their implementation are presented in Table 1.

On the basis of analysis of information from Table 1 , it can be concluded that the choice of strategy is largely determined by the current position of the company on the market. Moreover, implementation of the strategies adopted in the surveyed group of enterprises is very similar and focuses on several basic elements, such as: increasing market share, developing distribution networks on domestic and foreign markets, diversifying production, improving the quality of products offered, reducing production costs, CSR.

A proposal of perspectives and measures of a balanced performance card for the surveyed companies

The point of departure while creating BSC is to define defining the general objectives of the surveyed companies within its previously distinguished perspectives (Tables 2-7). The discussion of the BSC planes begins with the financial perspective, as the goals and measures of this perspective allow, on the one hand, to define the financial objectives of the implemented strategy, and at the same time constitute the target tasks for other BSC areas. The general objectives contained in the financial perspective (Table 2) were adopted after analyzing the strategic possibilities of selected economic units presented in table 1 . The objectives formulated in the financial area result from the life-cycle phase of the enterprise and the possibilities of its growth and development.

It is generally assumed that the main goal of an enterprise is to meet the expectations of the owners in terms of maximizing the company's value. For 
Strategies and directions of their implementation in selected enterprises of the confectionery sector

\begin{tabular}{|c|c|}
\hline Strategy assumptions & Directions of implementation of the adopted strategy \\
\hline \multicolumn{2}{|r|}{ Otmuchów S.A. } \\
\hline $\begin{array}{l}\text { Striving to become a } \\
\text { leader on the domestic } \\
\text { confectionery market }\end{array}$ & $\begin{array}{l}\text { Expansion of sales network, growth and diversification of sales carried out in the area of } \\
\text { private label and B2B; focus on servicing large customers running network sales; achieving } \\
\text { a two-digit dynamics of sales revenues in strategic segments and a two-digit EBITDA } \\
\text { margin in 2016-2020. }\end{array}$ \\
\hline $\begin{array}{l}\text { Gaining new foreign } \\
\text { markets }\end{array}$ & $\begin{array}{l}\text { Diversification of sales directions; undertaking marketing activities aimed at acquiring } \\
\text { foreign markets; increase in the share of exports in total sales (by } 2020-40 \% \text { of sales } \\
\text { revenues). }\end{array}$ \\
\hline $\begin{array}{l}\text { Ensuring the quality of raw } \\
\text { materials and guaranteeing } \\
\text { their deliveries }\end{array}$ & $\begin{array}{l}\text { Diversification of suppliers of raw materials and services, which guarantees stability and } \\
\text { safety of production; implementation of the supply chain; the use of increasingly higher } \\
\text { quality raw materials (quality standards); ongoing monitoring of the prices of strategic raw } \\
\text { materials as well as trends on the market. }\end{array}$ \\
\hline $\begin{array}{l}\text { Improving the quality } \\
\text { and aesthetics of products } \\
\text { as well as customer } \\
\text { satisfaction }\end{array}$ & $\begin{array}{l}\text { Adjustment of products to new nutritional trends; elimination of unhealthy ingredients } \\
\text { from products (e.g. palm oil, phosphates); disinvestment in the area of pellets and crisps; } \\
\text { marketing of innovative, high-quality products in the breakfast and cereal products } \\
\text { segment; introduction of distinctive packaging for products. }\end{array}$ \\
\hline $\begin{array}{l}\text { Intensification of pro-social } \\
\text { activities }\end{array}$ & $\begin{array}{l}\text { Charity work; activities aimed at forming healthy eating habits among children and adults; } \\
\text { sponsoring sports and recreational events; activities for the protection of the natural environment. }\end{array}$ \\
\hline \multicolumn{2}{|r|}{ Wawel S.A. } \\
\hline $\begin{array}{l}\text { Increasing the share in } \\
\text { the domestic market and } \\
\text { foreign markets }\end{array}$ & $\begin{array}{l}\text { Acquisition of new clients; increasing sales for export; expanding product assortments; } \\
\text { communication consistency of all product brands; permanent contracts with retail and } \\
\text { discount chains. }\end{array}$ \\
\hline $\begin{array}{l}\text { Ensuring the appropriate } \\
\text { quality of raw materials } \\
\text { and products as well as } \\
\text { customer service }\end{array}$ & $\begin{array}{l}\text { Organization of cooperation with producer groups; production of exceptional, highest } \\
\text { quality sweets; 'Good ingredients' project - improved recipes that do not contain } \\
\text { unnecessary preservatives, dyes or artificial flavors. Instead, they opt for high quality cocoa } \\
\text { beans, lecithin from certified soybeans (without GMO), gradual elimination of palm oil; } \\
\text { employment of experts on 'healthy nutrition'; product quality certification; monitoring } \\
\text { customer satisfaction. }\end{array}$ \\
\hline $\begin{array}{l}\text { Ensuring proper } \\
\text { relationships with suppliers }\end{array}$ & $\begin{array}{l}\text { Concentration on long-term contracts with suppliers of raw materials and services; } \\
\text { conclusion of future contracts for purchases of raw materials from abroad. }\end{array}$ \\
\hline $\begin{array}{l}\text { Increasing innovation and } \\
\text { production flexibility }\end{array}$ & $\begin{array}{l}\text { Expansion of distribution channels; analyzing market trends and directions of research and } \\
\text { development works in the industry in order to provide the Company with a competitive } \\
\text { position on the market through the development of the product portfolio, and organize and } \\
\text { conduct work on new research projects as part of the Research and Development Office. }\end{array}$ \\
\hline $\begin{array}{l}\text { Intensification of pro-social } \\
\text { activities }\end{array}$ & $\begin{array}{l}\text { The activity of the 'Wawel with the family' foundation; implementation of the 'You feel } \\
\text { well, you do well' strategy through which the company wants to put people in a good mood } \\
\text { and motivate to do good; implementation of socio-consumer programs, CSR activities } \\
\text { 'Heart is growing', the consumers can dedicate part of the payment for the product to } \\
\text { charity; pro-ecological activities. }\end{array}$ \\
\hline \multicolumn{2}{|r|}{ Colian Holding S.A. } \\
\hline Increase in market share & $\begin{array}{l}\text { Expanding the sales and export network by building strong regional and international } \\
\text { brands; introduction of 'impulse' and occasional products; maintaining the important } \\
\text { role of business in the area of B2B sales and private label, including the development of } \\
\text { cooperation with key clients in Poland and abroad; improvement in profitability through } \\
\text { the diversification of sales channels, including export development. }\end{array}$ \\
\hline Development of own brands & $\begin{array}{l}\text { Creating employee motivation systems to submit innovative ideas; introducing the 'blue } \\
\text { ocean strategy' based on finding a product niche on the market. }\end{array}$ \\
\hline $\begin{array}{l}\text { Improving the quality of } \\
\text { products }\end{array}$ & $\begin{array}{l}\text { Implementation and maintenance of the Quality Management System (quality certificates } \\
\text { HACCP and ISO9001, certificates of IFS (International Food Standard) BRC (British } \\
\text { Retail Consortium) trade standards; creation of recipes. }\end{array}$ \\
\hline Pro-social activities & Undertaking pro-ecological activities; sponsoring sports and recreational events. \\
\hline
\end{tabular}

Source: own study based on data from the financial statements of listed companies selected for the analysis. 
Financial perspective in BSC - goals and measures of their implementation

\begin{tabular}{|l|l|l|}
\hline \multicolumn{1}{|c|}{ General objectives } & \multicolumn{1}{|c|}{ General measures } & \multicolumn{1}{c|}{ Examples of activities } \\
\hline Raising ROE. & Return on equity (ROE). & $\begin{array}{l}\text { Increasing the company's profit rate. Optimization of the use of } \\
\text { assets. Optimization of financial structure and costs. }\end{array}$ \\
\hline $\begin{array}{l}\text { Increasing revenues from } \\
\text { sales and profits. }\end{array}$ & $\begin{array}{l}\text { Value of sales revenues. } \\
\text { Net profit. }\end{array}$ & $\begin{array}{l}\text { Balancing sales growth to financial possibilities. Taking actions } \\
\text { using the opportunity to increase the price. }\end{array}$ \\
\hline Optimization of costs. & Sales costs. & $\begin{array}{l}\text { Eliminating unprofitable products, replacing unprofitable } \\
\text { products with new, more profitable products. }\end{array}$ \\
\hline $\begin{array}{l}\text { Optimization of the use } \\
\text { of assets. }\end{array}$ & $\begin{array}{l}\text { Revenues from sales to } \\
\text { total assets. }\end{array}$ & $\begin{array}{l}\text { Intensification of activities for improving the productivity of } \\
\text { assets. }\end{array}$ \\
\hline
\end{tabular}

Source: authors' research.

this reason, in the financial perspective, achieving this goal is determined by the company's ability to continue and develop in the long run. Due to the fact that the surveyed companies are in the phase of maturity, sales revenues may increase as a result of the expansion of sales of products and goods to other countries (exports). Enterprises in the maturity phase should also be oriented towards cost reduction as well as better use of assets and optimization of the financial structure.

The next stage of 'mapping' the strategy is defining general goals in the area of the client (Table 3). They were determined based on the analysis of strategic possibilities in the aspect of further development of the analyzed enterprises. Increasing the share in the domestic and international market is possible thanks to gaining new customers and increasing the satisfaction of existing customers with the company's products. It also contributes to an increase in sales revenues

In the short term, an increasing market share is associated with the intensification of marketing activities aimed at expanding the sales network and winning foreign markets. In the long-term, it is particularly important to act to improve the company's image and increase the level of customer satisfaction, which is influenced by the high quality of products and goods offered, as well as their competitive price. The diversity of products that increases the attractiveness of the company's offer is also important. It affects the level of customer loyalty, contributing to the reselection of the products of the individual.

The goals in the financial and customer areas should be related to the objectives in the perspective of internal processes and learning, growth, suppliers and

\section{Customer perspective in BSC - objectives and measures of their implementation}

\begin{tabular}{|l|l|l|}
\hline \multicolumn{1}{|c|}{ General objectives } & \multicolumn{1}{|c|}{ General measures } & \multicolumn{1}{|c|}{ Examples of activities } \\
\hline $\begin{array}{l}\text { Increasing the share } \\
\text { in the domestic and } \\
\text { international market }\end{array}$ & $\begin{array}{l}\text { The share rate in the domestic market; the share rate in the } \\
\text { international market. }\end{array}$ & $\begin{array}{l}\text { Intensification of marketing } \\
\text { activities; development of } \\
\text { online or foreign sales. }\end{array}$ \\
\hline $\begin{array}{l}\text { Achieving a high level of } \\
\text { customer satisfaction and } \\
\text { increasing their loyalty }\end{array}$ & $\begin{array}{l}\text { Customer satisfaction index (results of the survey); the } \\
\text { number of customers who buy products again to the } \\
\text { number of customers; the number of customers willing to } \\
\text { recommend products to the number of customers. }\end{array}$ & $\begin{array}{l}\text { Intensification of marketing } \\
\text { activities. }\end{array}$ \\
\hline $\begin{array}{l}\text { Achieving high quality } \\
\text { and safety of products }\end{array}$ & $\begin{array}{l}\text { The percentage increase in expenditures on improving the } \\
\text { quality of products to the previous period; fair labeling of } \\
\text { products, as well as the number of detected irregularities } \\
\text { associated with it; quality and safety of products, as well as } \\
\text { the number of detected irregularities associated with it. }\end{array}$ & $\begin{array}{l}\text { Taking technological } \\
\text { initiatives. }\end{array}$ \\
\hline $\begin{array}{l}\text { Improving the image and } \\
\text { creating the company's } \\
\text { brand }\end{array}$ & $\begin{array}{l}\text { The percentage increase in funds for promotion and } \\
\text { advertising to the previous period, including funds for } \\
\text { educating consumers on issues related to commercial } \\
\text { activities, e.g. to increase consumers' ability to make } \\
\text { informed decisions about complex goods, services and } \\
\text { markets, to better understand the impact of their decisions } \\
\text { on the economy, the environment and society and to } \\
\text { promote sustainable consumption. }\end{array}$ & $\begin{array}{l}\text { Intensification of marketing } \\
\text { activities; brand promotion; } \\
\text { taking actions to educate } \\
\text { consumers on issues related } \\
\text { to commercial activities, } \\
\text { including the supply chain. }\end{array}$ \\
\hline
\end{tabular}

Source: authors' research. 


\section{Perspective of internal processes in BSC - objectives and measures of their implementation}

\begin{tabular}{|l|l|l|}
\hline \multicolumn{1}{|c|}{ General objectives } & \multicolumn{1}{|c|}{ General measures } & \multicolumn{1}{c|}{ Examples of activities } \\
\hline $\begin{array}{l}\text { Reduction in the number of } \\
\text { errors in the execution of } \\
\text { orders and shortening the time } \\
\text { of order fulfillment }\end{array}$ & $\begin{array}{l}\text { Number of justified complaints during the } \\
\text { year; waiting time for order fulfillment. }\end{array}$ & $\begin{array}{l}\text { Implementation of integrated IT } \\
\text { systems (e.g. for order tracking); } \\
\text { improving employee qualifications. }\end{array}$ \\
\hline $\begin{array}{l}\text { Development of distribution } \\
\text { channels }\end{array}$ & Number of new distribution channels in a year & Introducing online sale \\
\hline $\begin{array}{l}\text { Reduction of the unit cost of } \\
\text { production }\end{array}$ & The amount of the unit cost of production. & Introduction of modern technologies. \\
\hline $\begin{array}{l}\text { Modernization of the } \\
\text { machinery park }\end{array}$ & $\begin{array}{l}\text { Ratio in \% of outlays for the purchase of new } \\
\text { machinery to the net asset value. }\end{array}$ & $\begin{array}{l}\text { Purchase of new machines and } \\
\text { equipment. }\end{array}$ \\
\hline $\begin{array}{l}\text { Increasing the work safety of } \\
\text { employees }\end{array}$ & $\begin{array}{l}\text { Outlays on protective clothing, apparatus, etc., } \\
\text { in relation to the previous period. }\end{array}$ & $\begin{array}{l}\text { Actions to improve working } \\
\text { conditions. }\end{array}$ \\
\hline
\end{tabular}

Source: authors' research.

CSR. It allows to increase the efficiency of operations and motivate employees to implement the company's strategy. Objectives in the perspective of internal processes for the needs of sustainable enterprise growth are presented in Table 4.

Taking action to increase the quality of the products offered may positively affect the image of the company. Similarly, so can the implementation of business strategy related to the social aspect increasing the work safety of employees. Constant improvement of production efficiency requires investing in a modern machinery park. It contributes to the reduction of production costs and helps to optimize the structure of company costs (financial perspective), thanks to which there is the possibility of increasing margins on certain products and competing with the price while maintaining the existing margins on others. The reduction of costs is also conducive to the change of the financial structure due to the possibility of financing larger interest from the obtained external capital. The purchase of new machines and equipment also allows to increase the company's production capacity. The image and satisfaction of customers is also impacted by ensuring timely delivery of products, which is connected with the development of distribution channels and the introduction of IT systems for tracking deliveries. The improvement of the efficiency of customer service is also significantly influenced by reducing the number of errors in the execution of orders and shortening the expectations for their fulfillment.

At the BSC level, concerning growth and learning, the objectives related to employee development were defined above all (Table 5). It affects the effective implementation of tasks in the previously discussed BSC perspectives.

Table 5

\section{Perspective of growth and learning in BSC - objectives and measures of their implementation}

\begin{tabular}{|l|l|l|}
\hline \multicolumn{1}{|c|}{ General objectives } & \multicolumn{1}{|c|}{ General measures } & \multicolumn{1}{c|}{ Examples of activities } \\
\hline Raising employee qualifications & $\begin{array}{l}\text { The level of expenditures on the } \\
\text { development of employees in relation } \\
\text { to the plan; average number of training } \\
\text { hours per one employee. }\end{array}$ & $\begin{array}{l}\text { Acquiring EU funds for further } \\
\text { employee training; organization of } \\
\text { employee training at the headquarters } \\
\text { of the unit and outside it. }\end{array}$ \\
\hline Increased employee productivity & $\begin{array}{l}\text { Revenues from the sale of products - } \\
\text { consumption of materials and energy / } \\
\text { number of employees. }\end{array}$ & $\begin{array}{l}\text { Organization of employee training; } \\
\text { building employee incentive system. }\end{array}$ \\
\hline $\begin{array}{l}\text { Increasing employees' access to } \\
\text { modern technologies }\end{array}$ & $\begin{array}{l}\text { The amount of IT expenditure in relation } \\
\text { to one employee. }\end{array}$ & $\begin{array}{l}\text { Introduction of a modern order } \\
\text { fulfilment system. }\end{array}$ \\
\hline $\begin{array}{l}\text { Development of employee } \\
\text { incentive system }\end{array}$ & $\begin{array}{l}\text { The number of employees covered by } \\
\text { the incentive system. }\end{array}$ & Development of integration programs. \\
\hline $\begin{array}{l}\text { Motivating employees to propose } \\
\text { innovative ideas }\end{array}$ & $\begin{array}{l}\text { Number of ideas submitted per } \\
\text { 1 employee. }\end{array}$ & $\begin{array}{l}\text { Creating a motivational remuneration } \\
\text { system (bonuses, prizes). }\end{array}$ \\
\hline
\end{tabular}

Source: authors' reserch. 
Supplier's perspective in BSC - objectives and measures of their implementation

\begin{tabular}{|l|l|l|}
\hline \multicolumn{1}{|c|}{ General objectives } & \multicolumn{1}{|c|}{ General measures } & \multicolumn{1}{c|}{ Examples of activities } \\
\hline $\begin{array}{l}\text { Quality of relations with } \\
\text { suppliers }\end{array}$ & $\begin{array}{l}\text { Supplier satisfaction index; number of loyal } \\
\text { suppliers in relation to the total number of } \\
\text { suppliers }\end{array}$ & $\begin{array}{l}\text { Implementation of programs regarding } \\
\text { compliance with standards of integrity and } \\
\text { partnership }\end{array}$ \\
\hline Quality of transactions & $\begin{array}{l}\text { Average duration of obligation fulfillment; } \\
\text { durability of cooperation: the number of } \\
\text { contracts kept to the total number of contracts }\end{array}$ & $\begin{array}{l}\text { Undertaking activities to improve the } \\
\text { quality of cooperation }\end{array}$ \\
\hline $\begin{array}{l}\text { Managing the supply } \\
\text { chain }\end{array}$ & $\begin{array}{l}\text { Number of suppliers; number of contracts } \\
\text { with suppliers; number of actions aimed at } \\
\text { cessation or prevention of the negative effects } \\
\text { of activities within the supply chain }\end{array}$ & $\begin{array}{l}\text { Integration of suppliers around production } \\
\text { plants. Undertaking initiatives supporting } \\
\text { the creation of local / regional business } \\
\text { agreements }\end{array}$ \\
\hline $\begin{array}{l}\text { Securing the supply } \\
\text { of raw materials in the } \\
\text { long/short period }\end{array}$ & $\begin{array}{l}\text { Share of raw material purchased on the basis } \\
\text { of long-term contracts with agricultural } \\
\text { producers }\end{array}$ & $\begin{array}{l}\text { Intensification of marketing activities } \\
\text { Undertaking activities for the use of } \\
\text { financial instruments }\end{array}$ \\
\hline
\end{tabular}

Source: authors' research.

Table 7

The perspective of CSR in BSC - objectives and measures of their implementation

\begin{tabular}{|l|l|l|}
\hline \multicolumn{1}{|c|}{ General objectives } & \multicolumn{1}{|c|}{ General measures } & \multicolumn{1}{|c|}{ Environmental perspective } \\
\hline \multicolumn{3}{|c|}{ Exples of activities } \\
\hline $\begin{array}{l}\text { Care for the natural } \\
\text { environment }\end{array}$ & $\begin{array}{l}\text { Expenditure on environmental protection in relation to } \\
\text { operational cost plans. }\end{array}$ & $\begin{array}{l}\text { Actions to reduce pollutant and } \\
\text { waste emissions. }\end{array}$ \\
\hline $\begin{array}{l}\text { Raising the ISO audit } \\
\text { assessment }\end{array}$ & $\begin{array}{l}\text { The number of ISO and HACCP certificates confirming } \\
\text { the high quality of products }\end{array}$ & $\begin{array}{l}\text { Acquiring funds for } \\
\text { environmental protection }\end{array}$ \\
\hline Social perspective & \multicolumn{3}{|c|}{$\begin{array}{l}\text { Raising the quality of } \\
\text { relations with the public }\end{array}$} & $\begin{array}{l}\text { Enterprise image (survey); transparency of information } \\
\text { about the company's activity, including the percentage of } \\
\text { disclosures about CSR }\end{array}$ & $\begin{array}{l}\text { Increasing the transparency of } \\
\text { business information; taking } \\
\text { actions for the local community }\end{array}$ \\
\hline $\begin{array}{l}\text { Supporting local } \\
\text { development }\end{array}$ & $\begin{array}{l}\text { The amount of funds for infrastructure, the number of } \\
\text { social initiatives taken and the amount of funds to support } \\
\text { them, the amount of funds for charity, and the number of } \\
\text { jobs created, including for people with disabilities }\end{array}$ & $\begin{array}{l}\text { Supporting social and local } \\
\text { initiatives, charity activities, } \\
\text { sponsoring }\end{array}$ \\
\hline $\begin{array}{l}\text { Compliance with the } \\
\text { law, ethics and honesty }\end{array}$ & $\begin{array}{l}\text { Number of detected violations of legal norms, as well } \\
\text { as actions to eliminate them; number of actions against } \\
\text { bribery and corruption (policy, procedures for the } \\
\text { company and its employees). }\end{array}$ & $\begin{array}{l}\text { Taking actions to comply with } \\
\text { the law }\end{array}$ \\
\hline
\end{tabular}

Source: authors' research.

The development of a company also depends on employees who understand the strategic goals of the enterprise. Therefore, it is necessary to supplement knowledge and improve the qualifications of employees through training. It is also advisable to change the motivational system of employees with a view to shaping their behaviors oriented towards achieving the goals of the business and linking incentive systems with the implementation of the company's priorities. Highly qualified employees motivated to submit innovative ideas create and introduce new products offer interesting design, fast service and professional advice. Reducing the number of incorrect orders and shortening their execution time depends not only on the qualifications of employees, but also on their access to modern technologies. Increasing the access of employees to modern information technologies allows to improve or introduce modern systems of order fulfillment and to develop distribution channels, e.g. by introducing online sales.

In order to meet the requirements of the market, confectionery industry enterprises should have ensured and secured supplies of raw materials for production (Table 6). On the one hand, this involves contracting supplies, i.e. supplying raw materials on the basis of long- and short-term contracts concluded with groups of agricultural producers, fruit and vegetable producer groups and organizations, and 
on the other hand - establishing cooperation with producer groups that will be able to provide the adequate amount and quality of raw materials. For this reason, this perspective is particularly needed to provide information to optimize the supply chain.

The perspective of environmental protection can be considered in the context of obtaining quality certificates as well as other pro-ecological activities (Table 7). The construction of CSR meters may be based on areas defined according to GRI or ISO 26,000 (GRI and ISO 26,000, 2010).

Confectionery enterprises should care for the environment, taking pro-ecological measures to minimize their negative impact on the environment. This possibility is provided by the management of byproducts and post-production. It is also important to meet the quality standards compliant with HACCP and ISO 9001 and ISO 220000. Such actions also serve to improve the company's image, which translates into financial results.

\section{Conclusions}

As it follows from the considerations, the BSC for confectionery companies proposed in the article may be the basis for the construction of a system supporting management of these companies and early warning against threats. The proposed multidimensional performance measurement can be applied to all groups of food industry enterprises cooperating within the supply chain. Due to the specific nature of the operations of selected enterprises, it was proposed to include the perspective suppliers and CSR in the assessment of performance. The proposed measures of performance in the field of CSR support the assessment of the effects of the company's operations and determination of areas that require further improvement, which allows to recognize the potential negative effects of its impact on the environment more efficiently, and thus enables their prevention and mitigation. For individual perspectives, general objectives and performance measures as well as examples of actions enabling the implementation of the intended goals have been identified.

The management of the performance of confectionery companies, including CSR, can be used to improve their operations and contribute, among others, to:

1. improving the efficiency of the company's operation and strengthening its competitive position,

2. improving the image and reputation of the company, as well as relationships with particular stakeholder groups,

3. increasing the involvement of individual groups of stakeholders in building shared values,

4. developing activities, including the introduction of innovations, enabling, among others increasing the safety and quality of products, efficient cooperation, supporting local, regional and national development, or improving the quality of life of local communities.

\section{References}

1. Bigliardi, B., \& Bottani, E. (2010). Performance measurement in the food supply chain: a balanced scorecard approach. Facilities. 28(5/6), 249-260. DOI: 10.1108/02632771011031493.

2. Brewer, P.C. (2002). Aligning Supply Chain Incentives Using the Balanced Scorecard. Supply Chain Forum: An International Journal, 3(1), 12-19. DOI: 10.1080/16258312.2002.11517094.

3. Brezuleanu, S., Brezuleanu, C.O., Brad, I., Iancu, T., \& Ciani, A. (2015). Performance assessment in business of agricultural companies using balanced scorecard model. Cercetari Agronomice in Moldova, 48(2), 109-120. DOI: 10.1515/cerce-2015-0035.

4. Cardoso, A.A.B., Lopes, M.A., de Melo Carvalho, F., Ferrazza, R.A., Lima, A.L.R., \& Cardoso, M.G. (2017). Balanced scorecard as support to management decisions: case study in a small property of milk production. Scientia Agraria Paranaensis, 16(2), 158-165.

5. GRI and ISO. 26000: How to use the GRI Guidelines in combination with ISO 26000. (2010). Global Reporting Initiative (GRI), Retrieved March 01, 2019, from https://www.iso.org/files/live/sites/isoorg/files/archive/pdf/en/ iso-gri-26000_2014-01-28.pdf.

6. Hernández, C., Rickert, U., \& Schiefer, G. (2003). Quality and Safety Conditions for Customer Satisfaction on the whole Meat Chain: The Organization of Quality Communication Systems. EFITA2003: Information technology for a better agri-food sector, environment and rural living, 2, 575-580.

7. Jaworska, E., \& Nadolna, B. (2010). Budowa zrównoważonej karty dokonań na przykładzie wybranych przedsiębiorstw przetwórstwa rolno-spożywczego (Construction of Balanced Scorecard on the Example of Selected Agri-Food Processing Enterprises). Annals of the Polish Association of Agricultural and Agribusiness Economist, 12(3), 149-156. (in Polish)

8. Jaworski, J., \& Kondraszuk, T. (2013). Ramy koncepcyjne zastosowania strategicznej karty wyników w gospodarstwie wiejskim (Application of the Balanced Scorecard in Family Farm Management). Theoretical Journal of Accounting, 74 (130), 45-63. DOI: 10.5604/16414381.1085924. (in Polish) 
9. Kaplan, R.S., \& Norton, D.P. (1992). The Balanced Scorecard - Measures that Drive Performance. In: Harvard Business Review, January-February, 71-79.

10. Kaplan, R.S., \& Norton, D.P. (1996). Using the Balanced Scorecard as a Strategic Management System. In: Harvard Business Review, January-February: 75-85.

11. Kaplan, R.S., \& Norton, D.P. (2010). Wdrażanie strategii do osiągnięcia przewagi konkurencyjnej (The Execution Premium. Linking Strategy to Operations for Competitive Advantage). Warszawa: PWN. (in Polish)

12. Nita, B. (2014). Sprawozdawczość zarządcza (Management reporting). PWN, Warszawa. (in Polish)

13. Noell, C., \& Lund, M. (2003). The Balanced Scorecard (BSC) for Danish farms-vague framework or functional instrument? In: Farm management. Proceedings of the Nordic Association of Agricultural Scientists Seminar no. 345, 187-204.

14. Paustian, M., Wellner, M., \& Theuvsen, L. (2015). The Balanced Scorecard as a Management Tool for Arable Farming. Proceedings in Food System Dynamics, 262-275.

15. Pietrzak, M. (2008). Balanced Scorecard jako podstawa oceny spółdzielni mleczarskich (The Balanced Scorecard concept as the basis for assessing dairy cooperatives). Annals of The Polish Association of Agricultural and Agribusiness Economist, 10(3), 443-449. (in Polish)

16. Porter, M.E., \& Kramer, M.R. (2006). The link between competitive advantage and corporate social responsibility. Harvard Business Review, 84(12), 78-92.

17. Rynek słodyczy w Polsce. Edycja 2014 (Confectionery market in Poland). KPMG, Retrieved March 01, 2019, from https://assets.kpmg/content/dam/kpmg/pl/pdf/2016/12/pl-Rynek-slodyczy-w-Polsce-2014-onlinesecured.pdf. (in Polish)

18. Soliwoda, M. (2016). Zrównoważona Karta Wyników jako instrument strategicznego zarządzania finansami w polskich gospodarstwach rolniczych-wyzwania i szanse (Balanced scorecard as an instrument of strategic financial management in polish farms: challenges and opportunities). Finance, Financial Markets, Insurance, (5 (83) Part 2. Market conditions of micro, small and medium enterprises: Microfirma). 139-149. DOI: 10.5604/00441600.1167245. (in Polish) 